\title{
Assessing Landscape Pattern Relationship with Dengue Incidence in Peninsular Malaysia
}

\author{
N. Mohamad a, W. Y. W. Ibrahim ' , A. N. M. Ludin (D) a \\ ${ }^{a}$ Department of Urban and Regional Planning, Faculty of Built Environment and Surveying, Universiti Teknologi Malaysia. \\ ${ }^{b}$ Department of Landscape Architecture, Faculty of Built Environment and Surveying, Universiti Teknologi Malaysia
}

Article Info:

Received: 27 Aug 2018

in revised form: 15 March 2019

Accepted: 30 April 2019

Available Online: 30 August 2019

\section{Keywords:}

Landscape pattern, Dengue incidence, Geographic Information System

\section{Corresponding Author:} Nuramalina Binti Mohamad Universiti Teknologi Malaysia Email: nuramalina.mohamad1211 @gmail.com

\begin{abstract}
Dengue is the most common urban disease that is most prevalent in tropical areas. WHO 2009 stated that these diseases has grown a public health concern due to the risk of dengue infection that has increased dramatically between 50 and 100 million cases every year. This issue was very corresponded with landscape and environment changes. The objective of this paper is to discuss how landscape patterns in relation to dengue incidence. Open website; idengue were highly contributed in this study to locate the most risky area for dengue fever incidence at the township level. Geographic information system (GIS) was used to demonstrate the spatial patterns of all dengue cases in Johor Bahru and Geoprocessing was used to measure the boundary of risk according to the distribution of dengue outbreak. After that, to analyze the spatial landscape pattern, satellite images were used. Spatial descriptive analysis shows nonstrata housing, open space, road, planned commercial, strata housing and drainage system network is the most prevalence land use activity for dengue incidence in Iskandar Region. The finding shows the common landscape composition that relates to dengue cases. In conclusion, the future development of land use should be considered on landscape pattern towards rapid urbanization.
\end{abstract}

Copyright (C) 2019 GJGP-UNDIP This open access article is distributed under Creative Commons Attribution (CC-BY-NC-SA) 4.0 International license.

How to Cite (APA 6 th Style):

Nuramalina, M., Ibrahim, W.Y.W., \& Ludin, A. N. M. (2019). Assessing Landscape Pattern Relationship with Dengue Incidence in Peninsular Malaysia. Geoplanning: Journal of Geomatics and Planning, 6(1), 31-42. doi:10.14710/geoplanning.6.1.31-42.

\section{INTRODUCTION}

Dengue fever is the most important vector-borne disease (Aedes mosquitoes) in tropical areas. The disease has grown a public health concern due to the risk of dengue infection that has increased dramatically between 50 and 100 million cases every year (Nathan et al., 2009). It is predictable that dengue cases can be one of the serious vectors borne disease in Asian region especially in Malaysia if there is no vector effective control and action are taken. These bad scenarios are getting worse usually during monsoon seasons where there was in the spell of wet weather (Pang \& Loh, 2016). It has a complex relationship with environmental factors that influence the transmission of dengue infections such as the environment, climate and weather, human behaviour and immunity among the human population (Cheong et al., 2014; Xiang et al., 2017). United Nation Development Programme 2018 goals are to achieve the target whereby 2030, end the epidemics of AIDS, tuberculosis, malaria and neglected tropical diseases and combat hepatitis, water-borne diseases and other communicable diseases. According to Pang et al. (2017) the risk of dengue is now higher due to the urbanization and globalization process. Instead increasing the dengue immunity, decreasing the mosquito population is very important. Mosquito population and habitat rely on the urban landscape pattern.

The relationship between urban landscape and dengue incidences is apparent where the landscape structure composition in urban areas prominently influenced the dengue incidences (Cheong et al., 2014). Colonization of new habitat can be demolished by the process of land use changes. Land use changes can extend or reduce of the new habitat. In fact, land use and landscape changes can modify the composition of the mosquitoes because vector species rely on their new habitat preferences (Patz \& Norris, 2004). Land use and land cover change now recognized as an important driver of disease. For emerging or re-emerging 
infectious diseases, landscape change offers context and serves as a likely proximate driver of risk particularly when considering vector-borne or zoonotic diseases (Messina et al., 2015). The transformation process of landscape significantly related to the dengue incidences where the composition of land use types and land covers are the factors associated with mosquito ecology. In relation with scenario, the aim of this study is to shows landscape pattern that affected dengue incidence with the four important factors which is socio-economic, environment, human behaviour and land use and land cover.

\section{DATA AND METHODS}

\subsection{Study Area}

Located strategically in the heart of Asia at southernmost tip in peninsular Malaysia. World busiest shipping routes and possesses an abundance of natural and human resources. Iskandar Region Development (Figure 1) were expected 3 million people in 2025 and now it is home to 1.6 million people. It was selected because undergoing rapid urbanization. Iskandar Malaysia region is a comprehensive development region that covers $221,634.1$ hectares $(2,216.3$ square $\mathrm{km})$ of land area at the most southern part of Johor consisting the whole of Johor Bahru district and some areas in Pontian district. However, this study only focuses on 6 district which is Tebrau, Bandar Johor Bahru, Jelutong, Pulai, Tanjong Kupang and Sg. Tiram. By taking Johor Bahru as a study area undergoing rapid urbanization process, that will significantly change the future landscape scenario. The final result will determine the most risk land use and factors for dengue cases based on the condition of landscape composition and land use type configuration in the urbanization process of Johor Bahru.

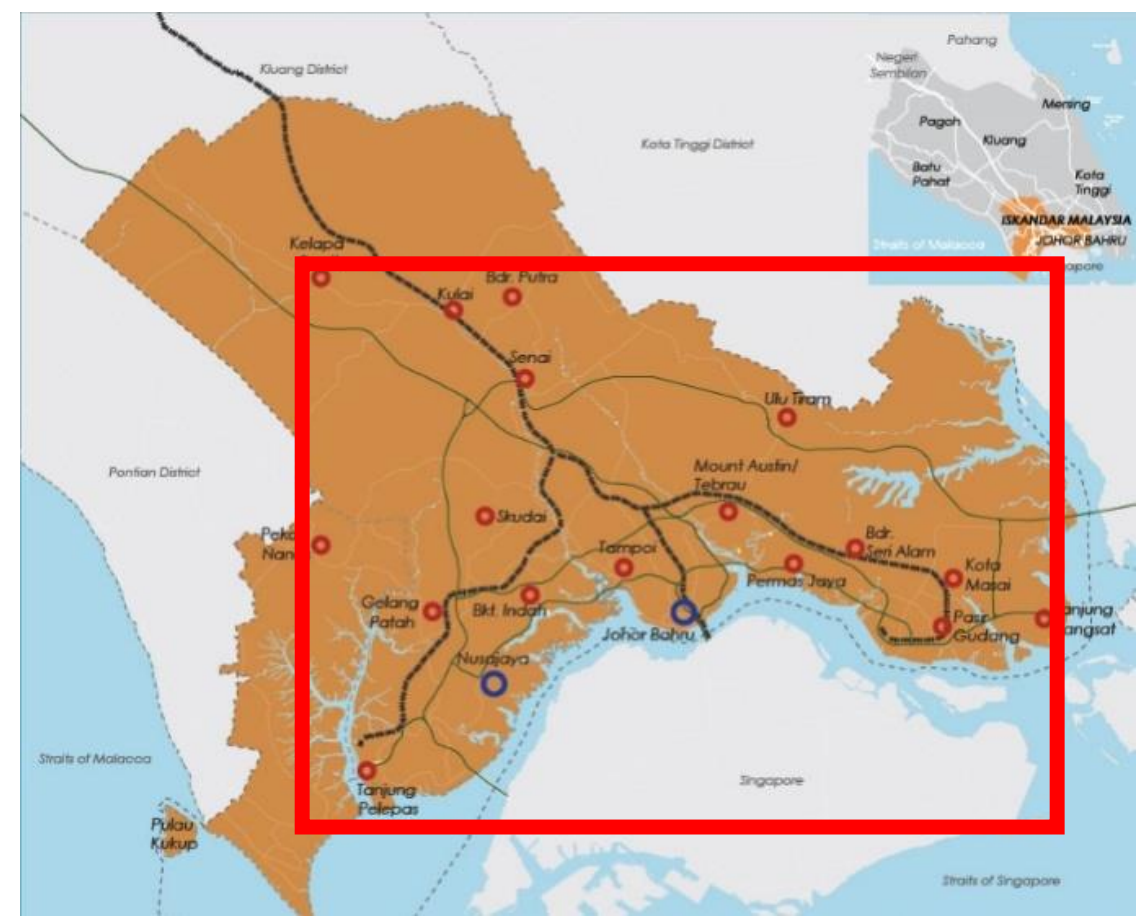

Figure 1. Key plan of Iskandar Malaysia

\subsection{Methods}

Several stages were involved in the study such as database development, database analysis and synthesis. Figure 2 shows the framework of the study that describes sequence of the process in this research. The first stage of this research is clarifying the relationship of dengue incidence with landscape pattern through literature review. After that, dengue incidence data was extract from the website idengue. Dengue cases from March, April and May 2018. After that longitude \& latitude of the location were geocode by using ArcGIS. A pair of coordinates represents a points of dengue incidence. The location of the cases was plot to the map as well as the number of cases by using the method of kernel density through ArcGIS application. After that, land use data 2016 were layered to figure out the cluster area. 


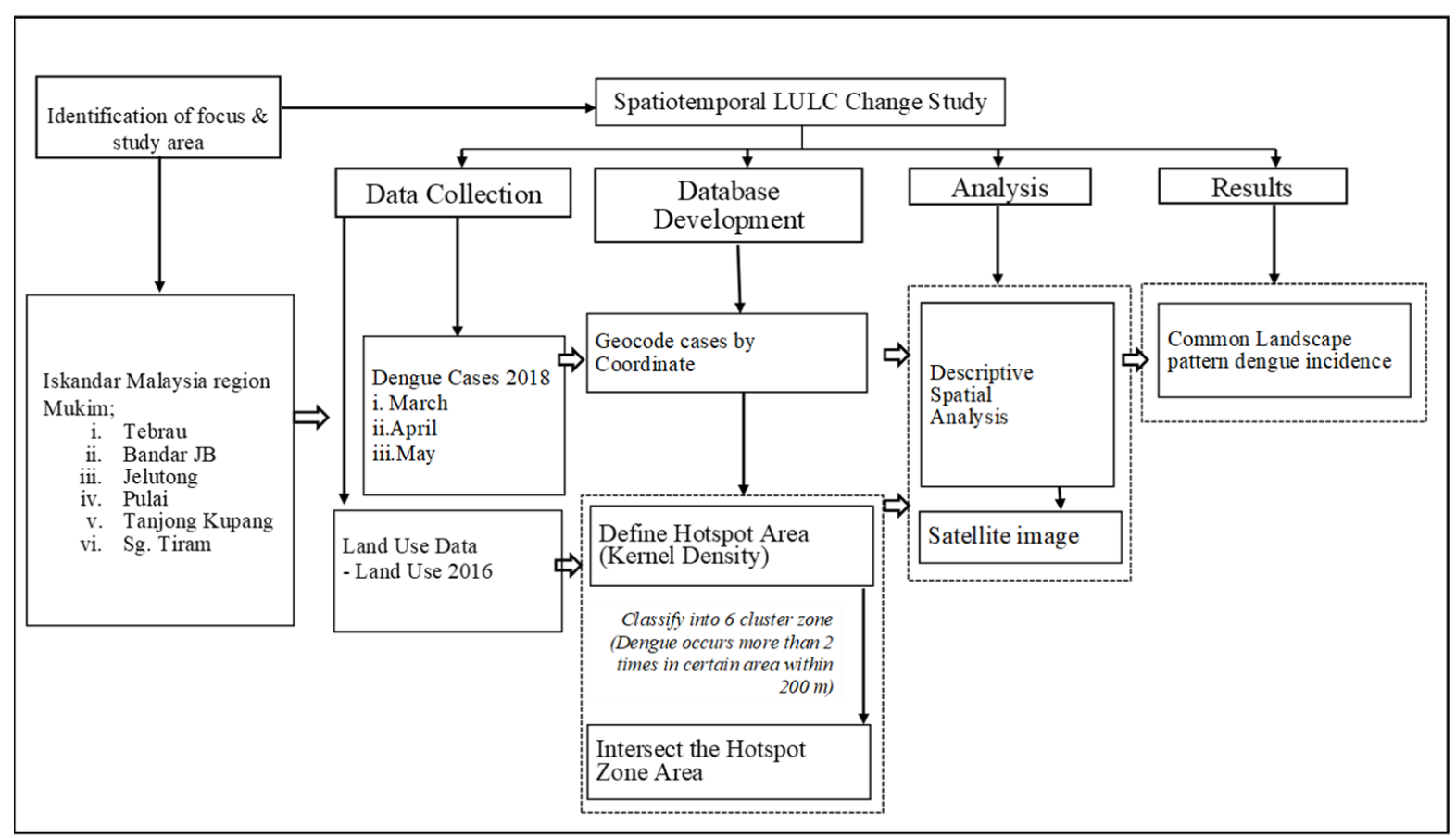

Figure 2. Research Framework

Dengue cases were classify by zone and analysed by the cluster area within $500 \mathrm{~m}$ as dengue cluster area is the area where two or more dengue cases occur within the 200 meter radius area of the index case within 14 days from the date of notification of the index case (Figure 3). There are 6 zone were classify within this area whereby this zone will analyse more detail. Meanwhile, there are several categories of land uses activity classified such as non-strata housing, open space, planned commercial, schools, mosque, police station, drainage, pump house and etc (Figure 4). After that the cluster area were overlay with land use map and intersect within $500 \mathrm{~m}$ to more focus on spatial landscape area.

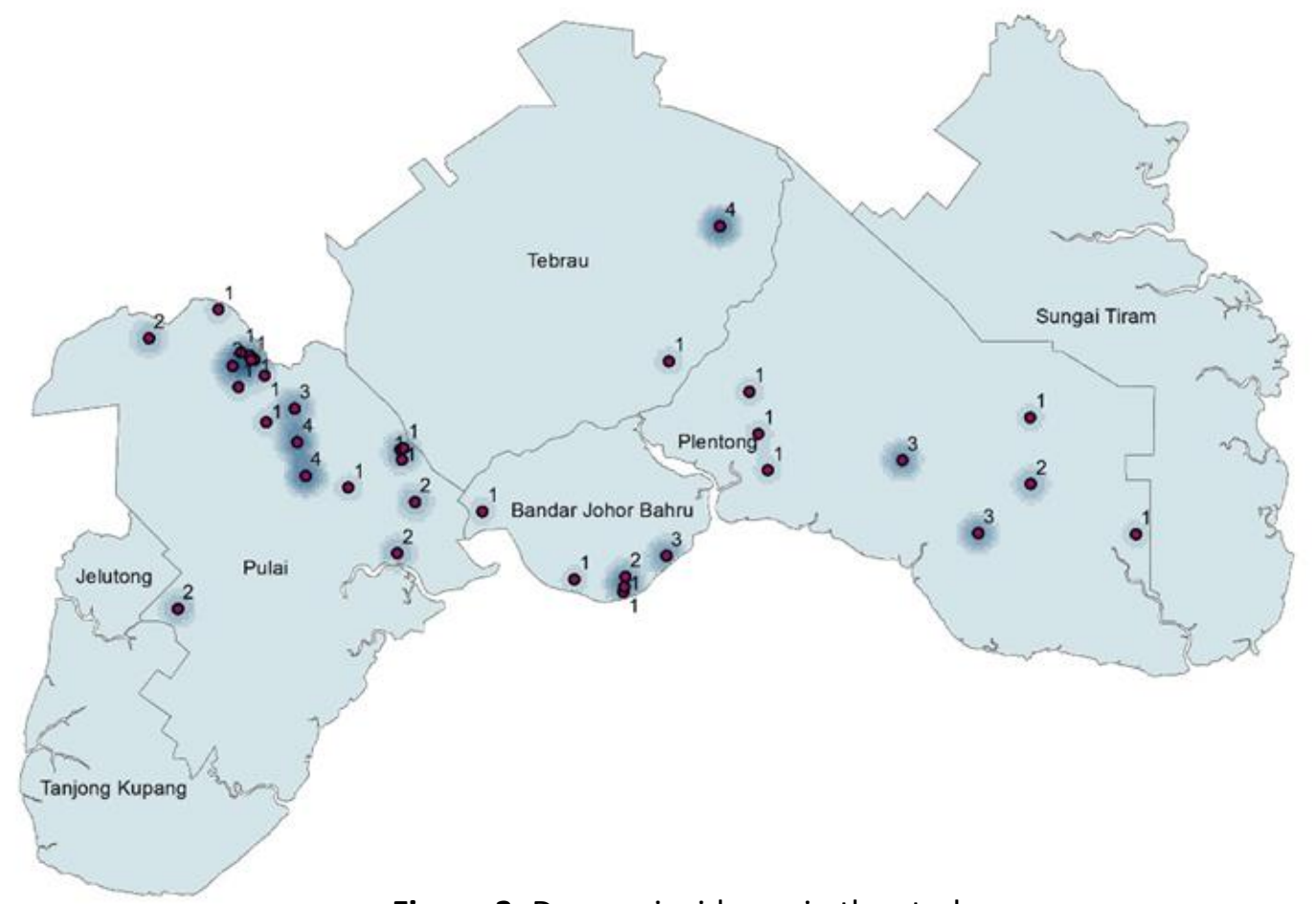

Figure 3. Dengue incidence in the study area 


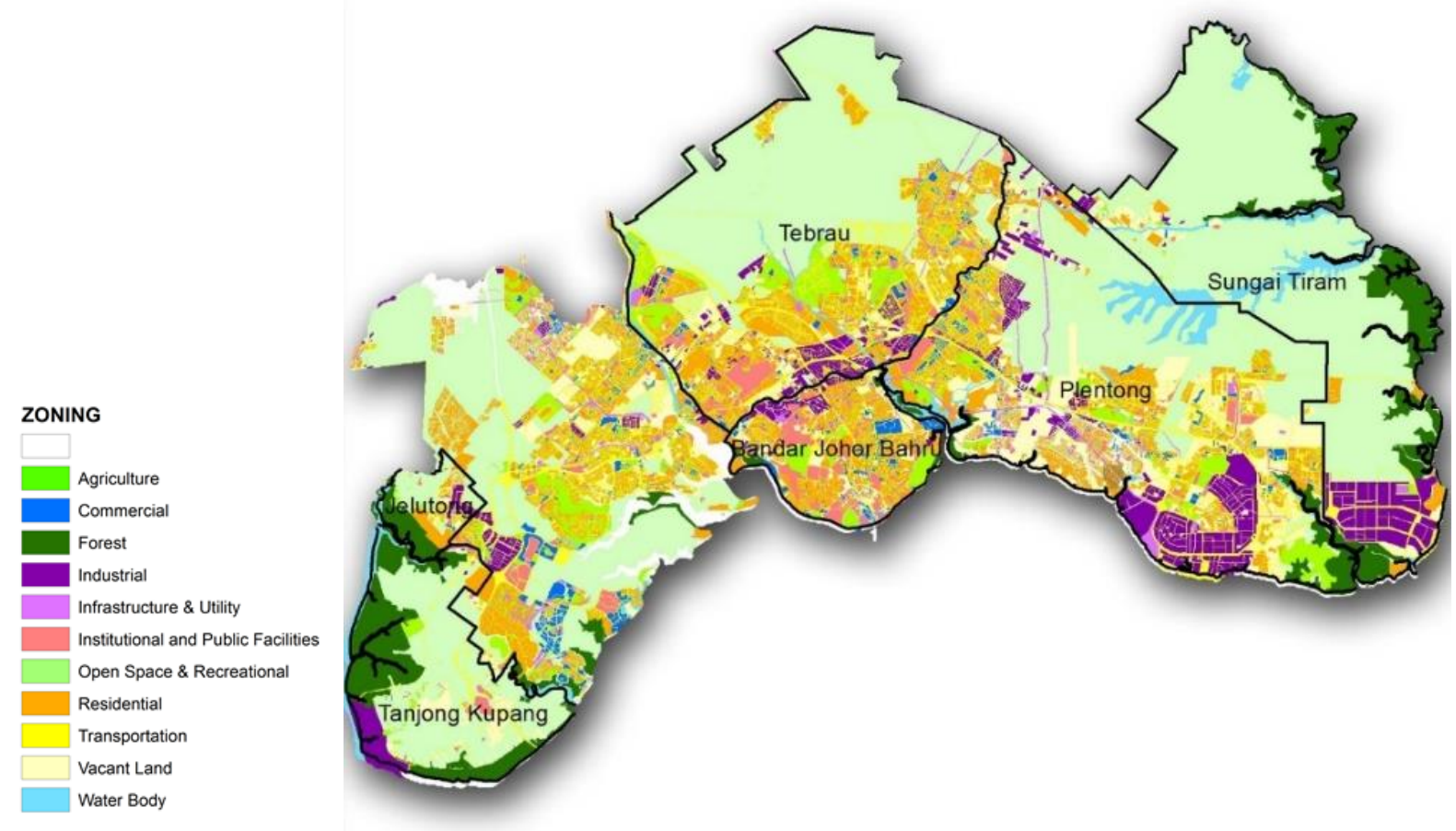

Figure 4. Type of land use within the study area

\section{RESULTS AND DISCUSSION}

\subsection{The Prevalence of Land Use Activity}

\section{a. Zone A}

Zone A is located at Pulai district where there have 9 cases from March until May. Table 1 shows the exact location and the number of cases. Graph shows non strata housing is the highest percentage with $35.04 \%$ follow by planned commercial with $12.62 \%$ and bushes $9.49 \%$ (Figure 5). This result consequence with the theory by Whitehorn \& Farrar (2010) Aedes aegypti prefer in urban context and high population density area. There several type of housing pattern in this zone and most dominated with terrace house; single storey. Besides, another type that also popular at this zone is Apartment type of housing which is Apartment Meranti and Apartment Melawis at Taman Universiti. This zone A is the centre for local people at Pulai district to buy their groceries, and for outsider for sightseeing since this area are located with commercial area which is U Mall, Skudai, Aeon Taman U, Taman Rekreasi Majlis Pebandaran Johor Bahru, Gunung Pulai and other commercial shop houses where correlated with the result whereby the second most highest percentage is planned commercial area.

Moreover, bushes can be categorized as the highest prevalence of land use activity for dengue incidence. There are many reasons on how the certain location can be a bushes spot area it is either the owner of the land did not maintain well or the land is the abundance area that belongs to government or any other developer or agencies. These bushes can cause the water flow stop and the water stagnant will develop into breeding site for Aedes mosquitoes. Recently, studies show that dengue vectors have been captured in vegetated areas and it can be found in bushes area (Hayden et al., 2010; Vezzani et al., 2005). However, drainage and open space got the highest percentage of land use activity in this cluster area. This type of land use activity was related with this research because Aedes mosquitoes will survive. Drainage system mostly depends on the water stream line which is natural source. This is another favourable dengue breeding site (Uribe et al., 2008). Open space such as field, Recreation Park and riverside can be categorized as public space. 


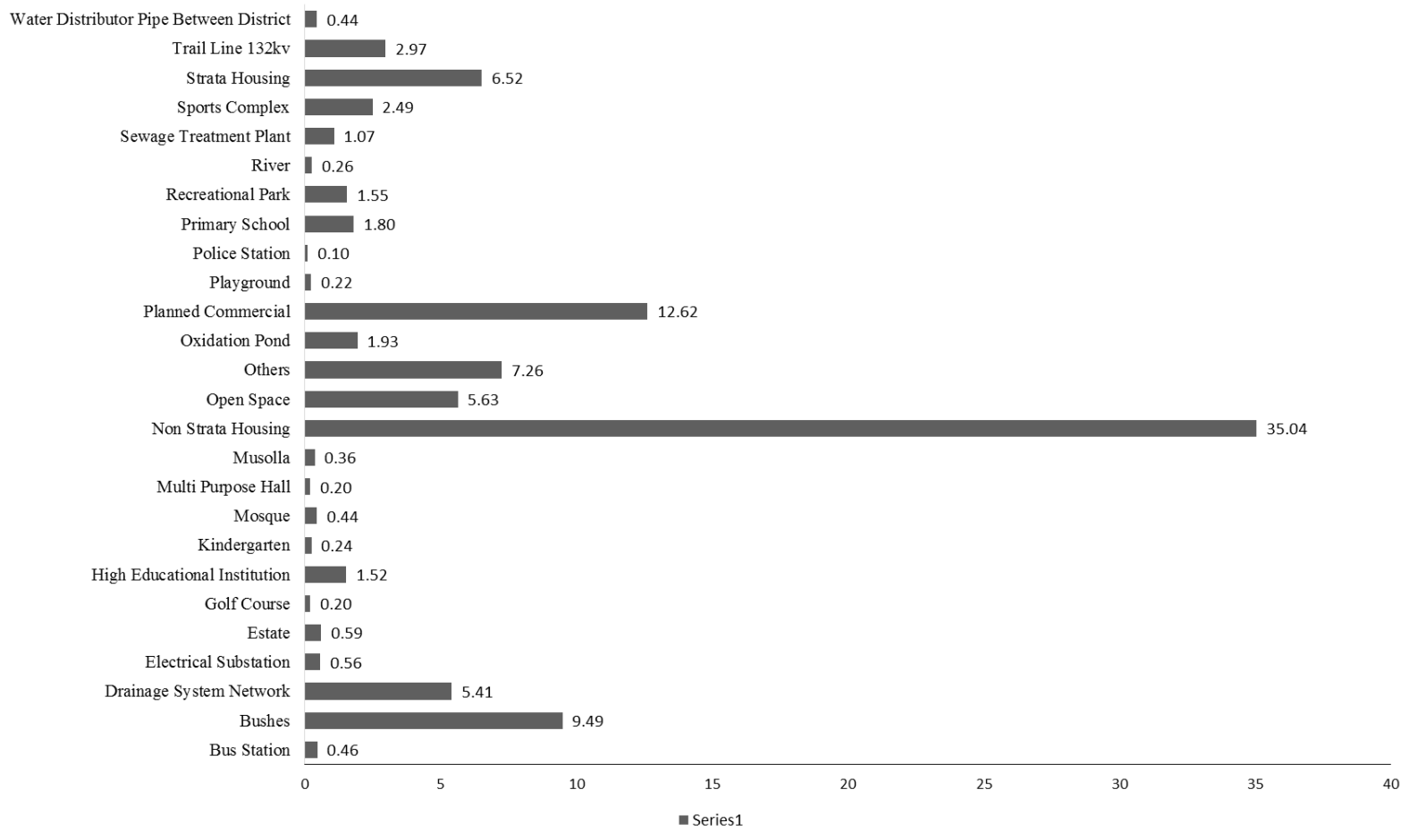

Figure 5. The percentage of land use activity in Zone A

Table 1. Land use map of Zone A

\begin{tabular}{|c|c|c|c|}
\hline \multicolumn{2}{|c|}{ Zone A Taman Universiti } & Satellite image & Land use map \\
\hline \multicolumn{4}{|l|}{ Zone A } \\
\hline \multicolumn{4}{|c|}{ Taman Pulai Utama, Jalan Pulai } \\
\hline $7-18$ & 1 & & \\
\hline \multicolumn{4}{|c|}{ Taman Pulai Indah, Jalan Pulai } \\
\hline \multirow{2}{*}{\multicolumn{4}{|c|}{$\begin{array}{l}\text { Indah } \\
\text { Taman Pulai Utama, Flat Taman }\end{array}$}} \\
\hline \multirow{2}{*}{\multicolumn{4}{|c|}{ Pulai Utama 3}} \\
\hline & & & \\
\hline \multirow{2}{*}{\multicolumn{4}{|c|}{ Meranti }} \\
\hline & \multicolumn{3}{|c|}{ Taman Universiti, Apartment } \\
\hline Melawis & 1 & & \\
\hline \multicolumn{3}{|c|}{ Taman Universiti, Kebangsaan } & \\
\hline \multicolumn{4}{|l|}{ Taman Universiti, Jalan } \\
\hline Pendidikan & 1 & & \\
\hline
\end{tabular}

\section{b. Zone B}

Location of zone 2 were at Taman Mutiara Rini and Taman Damai Jaya (Table 2). Taman Mutiara Rini is the most crucial area for cluster area dengue cases. Graph shows that approximately $26.01 \%$ of land use activity in cluster dengue area is pump house (water supply), $24.45 \%$ is non-strata housing and followed by bushes $16.37 \%$ (Figure 6). Pump house water supply is the main highest percentage in this zone. The result from this zone is very closely related to the recent studies by Cheong et al. (2014) that water element got the second highest percentage at the study area, Subang Selangor. Non strata housing is the second highest percentage because this zone is mainly used for residential area. Housing type for this cluster zone mostly were terrace house with double and single storey. However, there are certain location of housing area by terrace low cost house and apartment. 
Bushes and open space quite high in this zone because some land was belonging to other parties and they did not maintain well and become abundance land. Bushes land use activity is causes by excessive expansion of bush at the expense of other plant species, especially grasses. There are major causes of bushes encroachment (de Klerk, 2004), this is because the grass layer is over utilised, and loses the competitive advantage and can no longer use water and nutrients effectively. This results in a higher water and nutrient infiltration rate into the subsoil. Such a scenario will benefit trees and bushes and allow them to dominate. Bush will impact negatively or positively on biodiversity at certain context. A large number of mammals, bird species, reptiles and anthropoids are associated with the bush thickening in that area. However, if there are right densities of bush with mix of trees and shrubs there will produce more favourable sub habitat that resulting greater variety of herbaceous species which is good for ecological cycle. Local should aware on the routine of the removal of bushes because it will affect another plant to grow healthy (de Klerk, 2004). In South Africa Land cover data 2010, there were identified bushes as untransformed areas whereby the percentage woody thickening which is less than $20 \%$ (Stafford et al., 2017). Besides, the attitude of the local people does not really like to maintain the surround landscape. They let the bushes grow and did not realized it can give a negative impact.

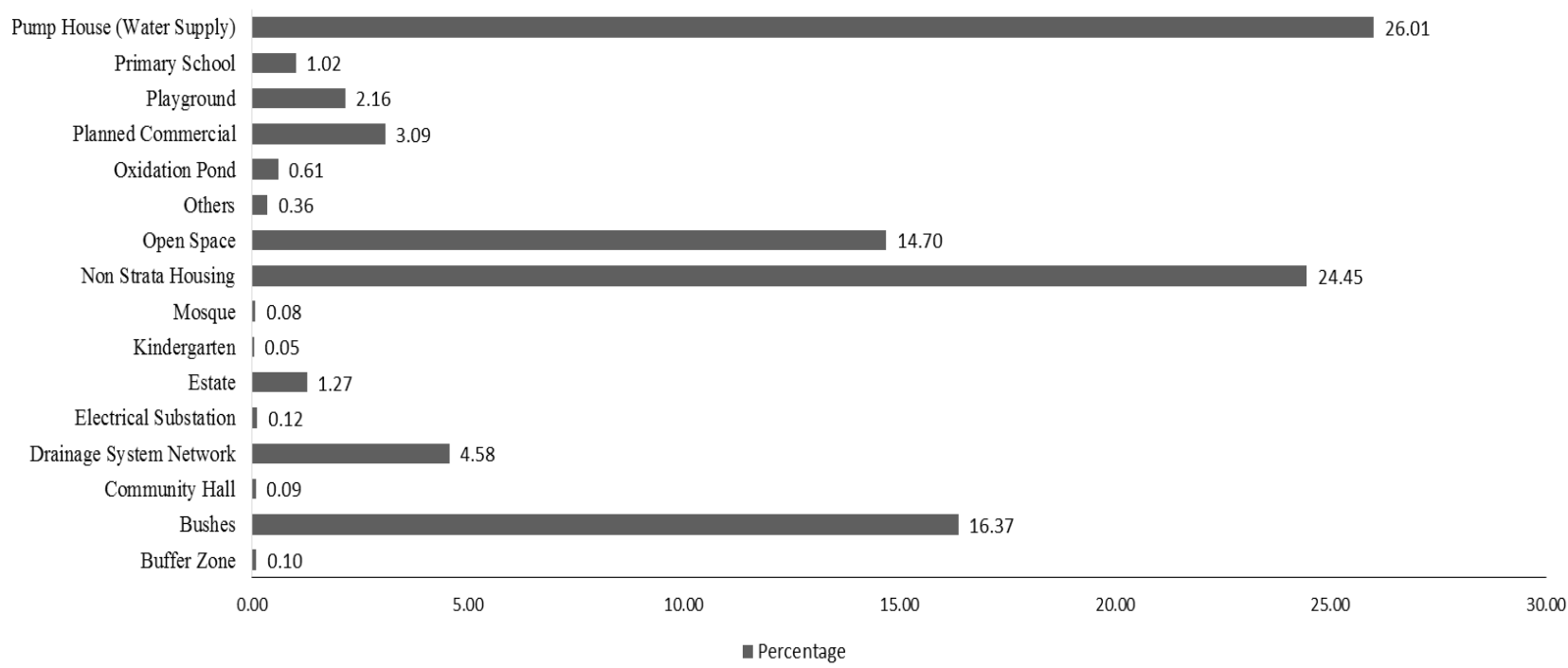

Figure 6. The percentage of land use activity in Zone B

Table 2. The land use map of zone B

\begin{tabular}{|c|c|c|}
\hline Zone B Taman Mutiara & Sattelite image & Land use map \\
\hline $\begin{array}{l}\text { Zone B } \\
\text { Zone } 2 \\
\text { Jalan Bakti 23, Mutiara Rini } \\
\text { Taman Mutiara Rini, Jalan } \\
\text { Utama 8-17 } \\
\text { Taman Mutiara Rini, } \\
\text { Pangsapuri Jasa } \\
\text { Taman Damai Jaya, Jalan } \\
\text { Makmur }\end{array}$ & $\begin{array}{l}\text { Cases } \\
4 \\
3 \\
4 \\
4\end{array}$ & \\
\hline
\end{tabular}




\section{c. Zone C}

The first influenced land use activity for dengue cases in zone C are open space 5.8\% followed by non-strata housing 5.0\% and bare earth 3.7\% (Figure 7). There are located near to Sungai Sekudai with total 3 dengue cases from March to May (refer Table 3). Sungai Sekudai is one of the potential natural resource for Johor Bahru that need to develop to become as one of recreation area. However, now this area become bare land and not develop that can cause negative impact for health and environment to the context area.

1

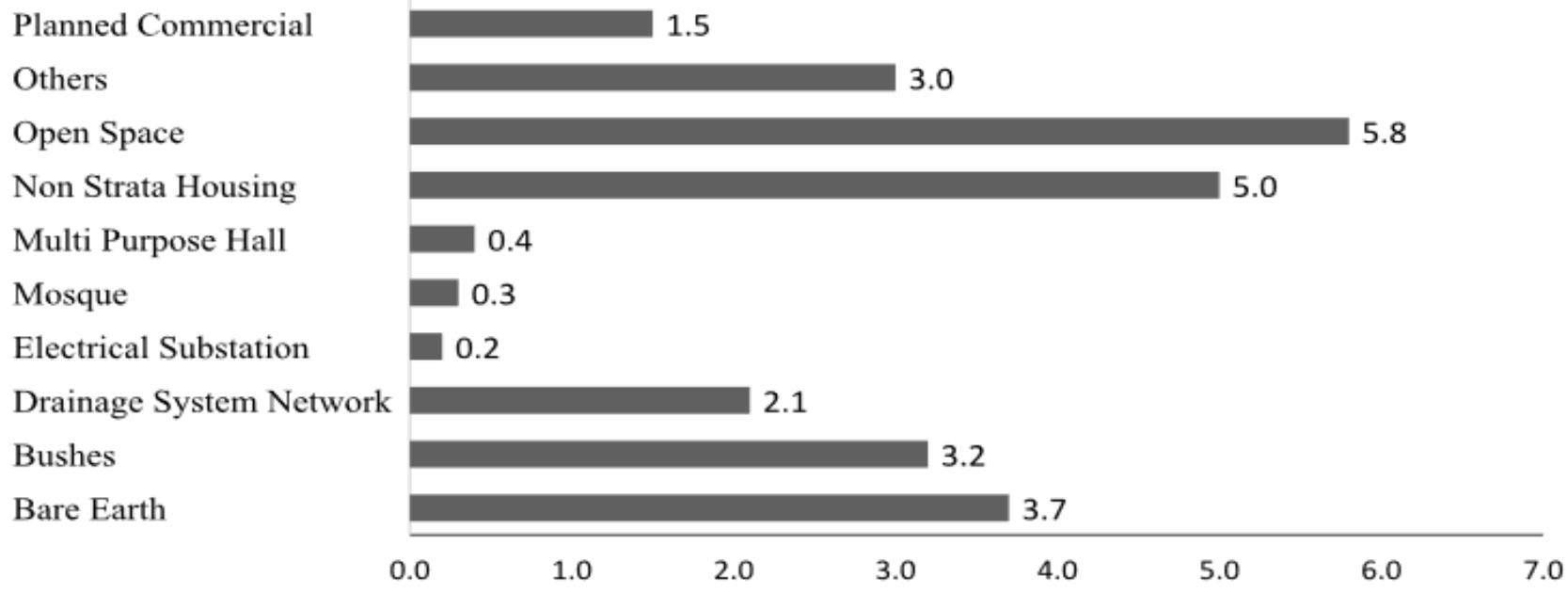

Figure 7. The percentage of land use activity in Zone C

Table 3. The land use map of zone $\mathrm{C}$

Zone C (Bandar JB District)
Zone C
Zone C
Taman Tampoi Indah 2,
$\begin{aligned} & \text { Apartment Sri Kenari } \\ & \text { Taman Tampoi Indah 2, } \\ & \text { Apartment Park Avenue } \\ & \text { Lily and Jasmine Apartment, }\end{aligned}$
Jalan titiwangsa Utama

\section{d. Zone D}

The highest percentage of this zone are planned commercial with $15.21 \%$ followed by non-strata housing $11.67 \%$ and open space $8.14 \%$ (Table 4). This zone located at the centre of Johor Bahru town. Johor Bahru is the crowded place and act as focal point for outsider and visitors to stay at nearest hotel. Nowadays, travel played an important factor to the distribution of dengue virus and it is associated with the Pucallpa outbreak during 2012. Non strata housing is the second highest percentage in this zone. Mostly time of housing in this area was flat and apartment at Flat Stulang Laut, Jalan Stulang. This type of housing which is flat and apartment are with high population density. Besides, people prefer to live and stay at this area because this zone are very accessible to others places and facilities. Apart from that, open space also is the 
highest percentage in this zone. Since this is busiest area, there a lot of transportation network and traffic. This is related with the theory by Wen et al. (2012) that human and movement of individuals could potentially increase the distribution of dengue infections as it can go beyond the dispersal range of mosquito population and can causes large scale outbreaks. Recent studies show that human settlements also one of the spots of land use activity where there found Aedes mosquitoes breed in water filled containers (Nyamah et al., 2010).

Table 4. The land use map of zone $D$

Zone D

\section{Cases}

Bangunan Sultan 2

Iskandar

Jalan Segget JB 1

Flat Stulang Laut, 3

Taman Stulang

Laut
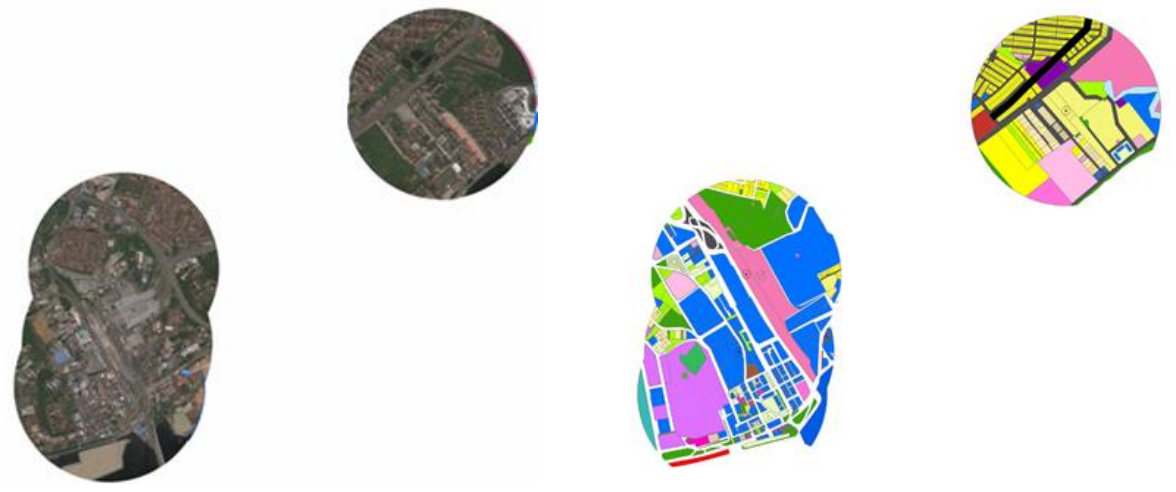

\section{e. Zone E}

The highest percentage of land use activity in zone $E$ is road network $29.33 \%$, non-strata housing $27.53 \%$ and open space $6.67 \%$ (Figure 8). This Zone E are located at Taman Puteri Wangsa (Table 5), Jalan Lading with 4 cases from March until May. Road network is the highest percentage because this housing area locate near to the major road network; Jalan Puteri. Housing pattern in this area mostly are low cost house; terrace with single storey and terrace with double storey. Apart, there are open space of an abundance and did no maintained well and filled with bushes.

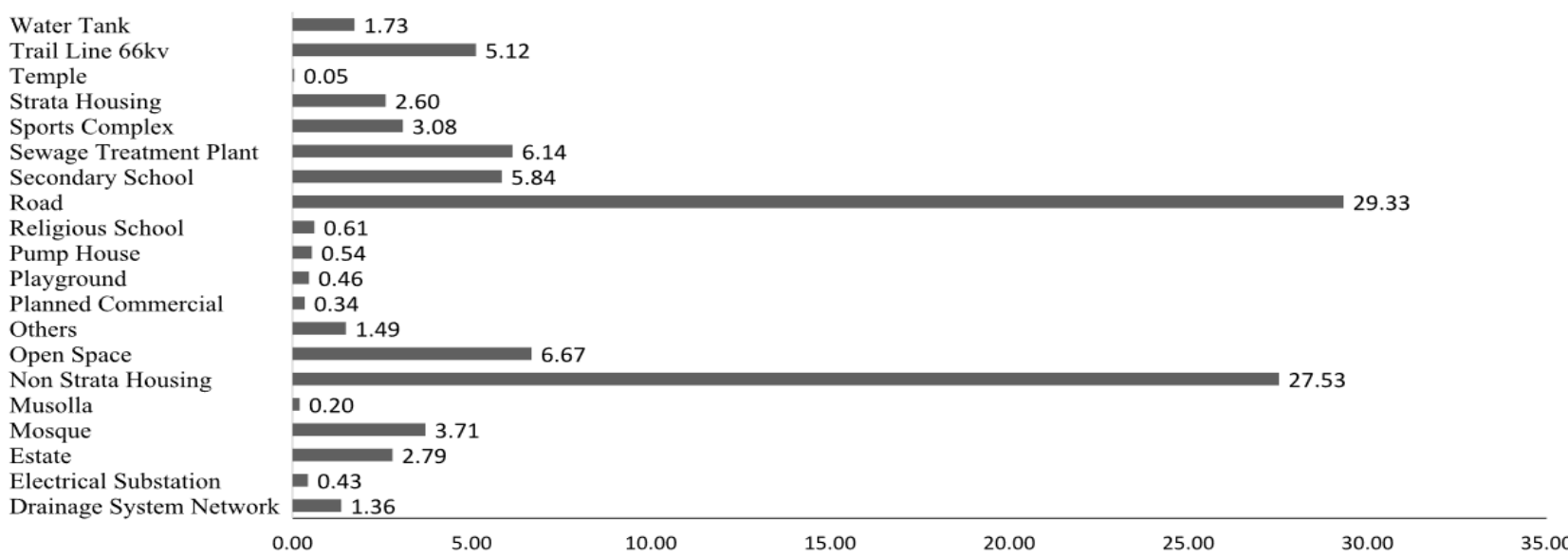

Figure 8. The percentage of land use activity in Zone $\mathrm{E}$ 
Table 5. The land use map of zone $\mathrm{E}$

Zone $\mathrm{E}$
Satellite image
$\begin{aligned} & \text { Zone } \mathrm{E} \\ & \text { Taman Puteri }\end{aligned}$
$\begin{aligned} & \text { Wangsa, Jalan } \\ & \text { Lading }\end{aligned}$
Cases

\section{f. Zone $F$}

The highest percentage of land use activity in this area are open space with $42.71 \%$ follow by road $39.58 \%$ and non-strata housing $13.13 \%$ (See Figure 9). This zone located at Jalan Sejambak (Plentong District). Mostly type of housing in this zone are terrace-double storey houses (Table 6). The composition of house is closer from another house and it is surround with open space where mostly filled with bushes.

Road

Recreational Park

Petrol Station

Open Space

Non Strata Housing

Buffer Zone

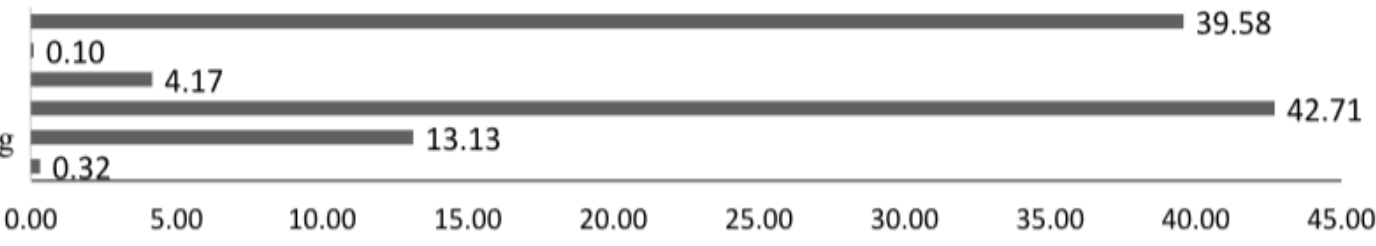

Z Zone 6

Figure 9. The percentage of land use activity in Zone F

Table 6. The land use map of zone $E$

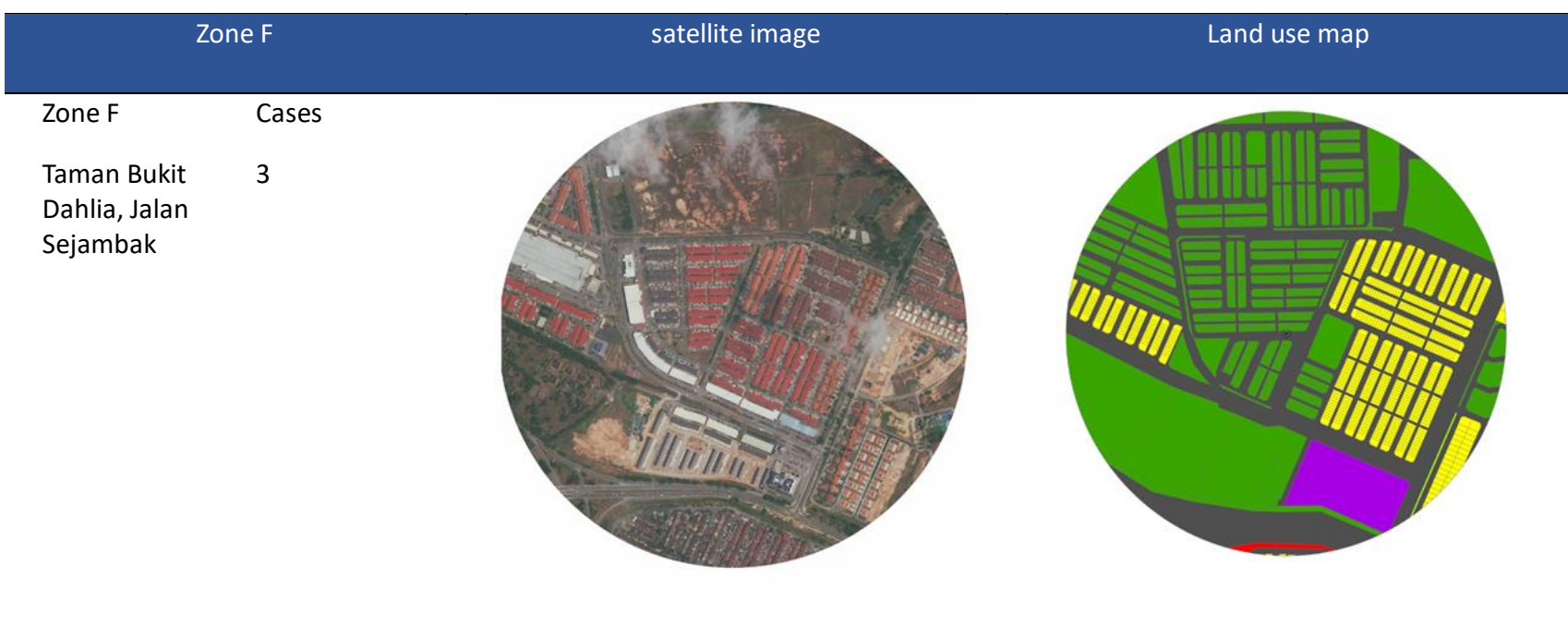




\subsection{Spatial Descriptive Analysis}

After calculate and considering of all type of land use activity, there is 6 type of land use activity which is the most risk for dengue incidence in Iskandar Region, Johor Bahru; (1) Non-strata housing, (2) Open space, (3) Road, (4) Planned commercial, (5) Strata housing and (6) Drainage system network. From all analysis zone $A, B, C, D, E$ and $F$ the most commonness land use activity is non-strata housing, open space, road, planned commercial, strata housing and drainage system network. There are several similarities of characteristic from all zone whereby most of land use for all zone are in urban context with high population density. According to Wu et al. (2009) the rapid growth of environment could lead to the increasing of dengue incidence. This is much related with this area where most of the dengue cases are happen in urban area. Housing is crucial area in this study whereby the pattern of the housing and the outdoor environment increased the possibilities of dengue transmission to other people. However, non-built up area such as open space, road and drainage network is part of the land use activity also acts as determinant of dengue mosquito's presence. All of this land use needs more attention for future planning since this is the most risk land use activity in Iskandar Region. Unplanned urbanization causes the development of breeding site and increasing the potential of Aedes mosquitoes to disperse.

Different context of housing has different type of landscape composition (Table 7). Most of the houses tend to have their own green space in front of their houses especially for terrace house. These cultures are related with recent studies by Rohani et al. (2011) whereby Malays prefers to have green element at their living spaces. Apart, well defined of landscape structure can boost the quality of neighbourhood context and provide a conducive living space in residential area (Shahli et al., 2014). However, this culture could lead to negative impact to the neighbourhood if they did not maintain well because most of the research has been prove that Aedes mosquitoes were trap at vegetated areas. Entomological studied prove that dengue vectors mostly found in vegetated areas, such as orchards, rubber plantation also in brackish water (Hayden et al., 2010; Vanwambeke et al., 2007; Vezzani et al., 2005). Besides, open spaces at this context mostly are abundance and filled with lot of bushes. This can support the Aedes mosquitoes breeding activities because some of the leaves can collect clean water and becomes a breeding site for them. This result was closely related with recent studies in Putrajaya where the residents aware that the risk of the potential breeding site at green space (Dickinson \& Hobbs, 2017). These land use activity; open space did not correspond with the theories by (Tyrväinen et al., 2007) where green space can improve the interaction and healthy lifestyle to the surrounds.

Table 7. Spatial descriptive in all zone

\begin{tabular}{|c|c|c|c|}
\hline No. & Total percentage all zone \% & Total hectare all zone $\mathrm{m}^{2}$ & No of Existency Zone \\
\hline 1 & Non-strata housing $117 \%$ & Non-strata housing 310.25 & Non-strata housing 6 Zone \\
\hline 2 & Open Space $84 \%$ & Pump houses 178.79 & Open space 6 zone \\
\hline 3 & Road $80 \%$ & Bushes 176.56 & Drainage system network 5 \\
\hline 4 & Planned Commercial 33\% & Open space 175.04 & Road 5 \\
\hline 5 & Bushes 30\% & Planned commercial 80.61 & Planned commercial 5 \\
\hline 6 & Pump House (water supply) 26\% & Road 69.41 & Strata housing 5 \\
\hline 7 & Strata Housing $20 \%$ & Strata Housing 65.92 & Electrical substation 5 \\
\hline 8 & Drainage System Network 14\% & Drainage System Network 49.65 & Mosque 5 \\
\hline 9 & Secondary school $10 \%$ & River 23.98 & Water tank 4 \\
\hline
\end{tabular}

Other than that, road is very significant in urban planning design. According to Khormi and Kumar (2011). High qualities of neighbourhood which is have a wider street have a low risk of dengue infection while low qualities of neighbourhood which is have narrower street more potential for dengue infection. Major roadways are part of determinants to studies the existence of dengue (Mahabir et al., 2012). In contrast, the major motorways may form major barriers to the flying mosquitoes because the volume of traffic is greater on these roads and especially during blood feeding periods for mosquitoes (early morning 
and later evening) since these usually coincide with journeys to and from work (Mahabir et al., 2012).

By 2020, the forecast number of households increasing at a faster rate than the growth of population. This statement related with this site studies where most of the cluster zone with dengue cases are at low cost housing area (terrace and flat). UN Habitat 2003 forecast where the number of people living in this settlement is expected to increase to 2 billion by 2030. This fact should synchronize to strategies on how to improve living condition for poor and average people. UN Habitat, 2003 revealed the attributes and the condition of low-cost housing that relate with this research; lack of basic services, substandard housing or illegal and inadequate building structures, overcrowding and high density, unhealthy living condition and hazardous locations and poverty.

However there are strong reason why flat or apartment type of house become one of risk type land use activity for dengue cases, this is because multi-layer type of house lead increasing the shaded area of the context thus this could be a potential temperature for Aedes mosquitoes breeding where the ideal temperature for Aedes mosquitoes breeding is between 20-30 Celcius (Tun-Lin et al., 2000). According to Nazri et al. (2009) temperature and humidity of the environment are the core factors to influence the Aedes mosquito's performance; maturation, replication and their survival time. However, temperature can be one of the reasons for terrace house pattern. This is because from analyse of satellite image the house sizes are smaller and the houses are closer together. The closer of the house, the higher of shaded area. Landscape composition of the context area will affect the rate of dengue incidence in certain area. In short, the main character of dengue cases in landscape composition is housing (low cost house), green and open space, drainage system network, commercial area and road. All of this land use needs more attention for future planning since this is the most risk land use activity in Iskandar Region.

\section{CONCLUSIONS}

The future development of land use especially for residential and open space should be considered on landscape pattern towards rapid urbanization. This study shows that, the transmission of dengue cases is likely more on housing area; low cost house which is terrace and flat, commercial area, open space, road and drainage system network. All of this land use activity is the highest prevalence at dengue cluster area in Iskandar Region, Johor Bahru. However, others factor such as households waste, indoor environments of the housing must be considered.

\section{REFERENCES}

Cheong, Y. L., Leitão, P. J., \& Lakes, T. (2014). Assessment of land use factors associated with dengue cases in Malaysia using Boosted Regression Trees. Spatial and Spatio-Temporal Epidemiology, 10, 75-84. [Crossref]

de Klerk, J. N. (2004). Bush Encroachment in Namibia. Ministry of Environment and Tourism, Windhoek, Namibia.

Dickinson, D. C., \& Hobbs, R. J. (2017). Cultural ecosystem services: Characteristics, challenges and lessons for urban green space research. Ecosystem Services, 25, 179-194. [Crossref]

Hayden, M. H., Uejio, C. K., Walker, K., Ramberg, F., Moreno, R., Rosales, C., ... Janes, C. R. (2010). Microclimate and human factors in the divergent ecology of Aedes aegypti along the Arizona, US/Sonora, MX border. EcoHealth, 7(1), 64-77. [Crossref]

Khormi, H. M., \& Kumar, L. (2011). Modeling dengue fever risk based on socioeconomic parameters, nationality and age groups: GIS and remote sensing based case study. Science of the Total Environment, 409(22), 4713-4719. [Crossref]

Mahabir, R. S., Severson, D. W., \& Chadee, D. D. (2012). Impact of road networks on the distribution of dengue fever cases in Trinidad, West Indies. Acta Tropica, 123(3), 178-183. [Crossref]

Messina, J. P., Brady, O. J., Pigott, D. M., Golding, N., Kraemer, M. U. G., Scott, T. W., ... Hay, S. I. (2015). The many projected futures of dengue. Nature Reviews Microbiology, 13(4), 230. [Crossref]

Nathan, M. B., Dayal-Drager, R., \& Guzman, M. (2009). Epidemiology, burden of disease and transmission. WHO. Dengue Guidelines for Diagnosis, Treatment, Prevention and Control. New Edition. Geneva: WHO, 1-21.

Nazri, C. D., Hashim, A., \& Rodziah, I. (2009). Distribution pattern of a dengue fever outbreak using GIS. J Environ Health Res, 9(2), 89-96. 
Nyamah, M. A., Sulaiman, S., Omar, B., \& others. (2010). Categorization of potential breeding sites of dengue vectors in Johor, Malaysia. Trop Biomed, 27(1), 33-40.

Pang, E. L., \& Loh, H.-S. (2016). Current perspectives on dengue episode in Malaysia. Asian Pacific Journal of Tropical Medicine, 9(4), 395-401. [Crossref]

Pang, T., Mak, T. K., \& Gubler, D. J. (2017). Prevention and control of dengue-the light at the end of the tunnel. The Lancet Infectious Diseases, 17(3), e79--e87.

Patz, J. A., \& Norris, D. (2004). Land use change and human health. In Ecosystems and Land Use Change, 2004 (pp. 159-167). Blackwell Publishing Ltd.

Rohani, A., Ismail, S., Malinda, M., Anuar, I., Mazlan, I. M., Maszaitun, M. S., ... others. (2011). Aedes larval population dynamics and risk for dengue epidemics in Malaysia. Tropical Biomedicine, 28(2), 237-248.

Shahli, F. M., Hussain, M. R. M., Tukiman, I., \& Zaidin, N. (2014). The importance aspects of landscape design on housing development in urban areas. APCBEE Procedia, 10, 311-315.

Stafford, W., Birch, C., Etter, H., Blanchard, R., Mudavanhu, S., Angelstam, P., ... Marais, C. (2017). The economics of landscape restoration: Benefits of controlling bush encroachment and invasive plant species in South Africa and Namibia. Ecosystem Services, 27, 193-202. [Crossref]

Tun-Lin, W., Burkot, T. R., \& Kay, B. H. (2000). Effects of temperature and larval diet on development rates and survival of the dengue vector Aedes aegypti in north Queensland, Australia. Medical and Veterinary Entomology, 14(1), 31-37. [Crossref]

Tyrväinen, L., Mäkinen, K., \& Schipperijn, J. (2007). Tools for mapping social values of urban woodlands and other green areas. Landscape and Urban Planning, 79(1), 5-19. [Crossref]

Uribe, L. A. A., Pineda, S. V., Martinez, O. G., Flores, J. L., Davila, M. F., \& Harris, M. K. (2008). Culicid distribution in Coahuila, Mexico. Southwestern Entomologist, 33(3), 219-223.

Vanwambeke, S. O., Somboon, P., Harbach, R. E., Isenstadt, M., Lambin, E. F., Walton, C., \& Butlin, R. K. (2007). Landscape and Land Cover Factors Influence the Presence of Aedes and Anopheles Larvae. Journal of Medical Entomology, 44(1), 133-144. [Crossref]

Vezzani, D., Rubio, A., Velazquez, S. M., Schweigmann, N., \& Wiegand, T. (2005). Detailed assessment of microhabitat suitability for Aedes aegypti (Diptera: Culicidae) in Buenos Aires, Argentina. Acta Tropica, 95(2), 123-131.

Wen, T.-H., Lin, M.-H., \& Fang, C.-T. (2012). Population Movement and Vector-Borne Disease Transmission: Differentiating Spatial-Temporal Diffusion Patterns of Commuting and Noncommuting Dengue Cases. Annals of the Association of American Geographers, 102(5), 1026-1037. [Crossref]

Whitehorn, J., \& Farrar, J. (2010). Dengue. British Medical Bulletin.

Wu, P. C., Lay, J. G., Guo, H. R., Lin, C. Y., Lung, S. C., \& Su, H. J. (2009). Higher temperature and urbanization affect the spatial patterns of dengue fever transmission in subtropical Taiwan. Science of the Total Environment, 407(7), 2224-2233. [Crossref]

Xiang, J., Hansen, A., Liu, Q., Liu, X., Tong, M. X., Sun, Y., ... others. (2017). Association between dengue fever incidence and meteorological factors in Guangzhou, China, 2005-2014. Environmental Research, 153, 17-26. [Crossref] 